\title{
Zinc, calcium, protein, lead, mercury, and the sensorics quality of cireng snacks supplemented with blood cockle (Anadara granosa)
}

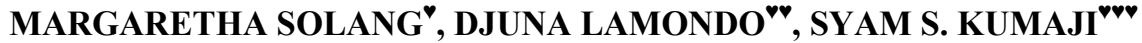 \\ Department of Biology, Faculty of Mathematics and Natural Sciences, Universitas Negeri Gorontalo. J1. Jenderal Sudirman No .6 Gorontalo City 96128, \\ Gorontalo, Indonesia. Tel.: +62-435-821125, Fax.: +62-435-821752. `email: margarethasolang@ung.ac.id, "^djunalamondo@ung.ac.id, \\ rvvsyam_bio@ung.ac.id
}

Manuscript received: 31 August 2017. Revision accepted: 21 November 2017.

\begin{abstract}
Solang M, Lamondo D, Kumaji SS. 2017. Zinc, calcium, protein, lead, mercury, and the sensorics quality of cireng snacks supplemented with blood cockle (Anadara granosa). Nusantara Bioscience 9: 385-391. Blood cockle (Anadara granosa) is a potential nutritious food with high economic value. This study aims at evaluating the level of zinc, calcium, protein, mercury, lead, and the sensorics quality of cireng (traditional Indonesian snack made from fried-tapioca flour dipped into sauces) supplemented with blood cockle. This study used complete randomised design, where the treatment factors consisted of flour made from blood cockles to supplement the flour used in making the cireng snacks. The concentration of the treatment factors were $0 \%, 5 \%, 10 \%, 15 \%$, and $20 \%$. The data were analyzed using the One Way ANOVA test and LSD test. This study shows that blood cockles' supplementation significantly increases the level of protein $(\mathrm{p}=0.05)$, zinc $(\mathrm{p}=0.031)$, calcium $(\mathrm{p}=0.016)$, lead $(0.000)$, mercury $(\mathrm{p}=0.022)$ of the cireng snacks. Supplementation of blood cockles has increased the preference toward cireng's flavor, aroma, and color by $10 \%$, whereas the level of preference toward the texture of cireng which used the blood cockle has increased by $20 \%$ compared to cireng product with non-supplemented flour. The level of lead $(\mathrm{Pb})$, and Mercury $(\mathrm{Hg})$ are below the Indonesian National Standard (SNI). Supplementation of blood cockles from Gorontalo in the flour used in making the cireng snacks produced snacks with a better nutrition value and safe to consume. Also, the flavor, color, texture, and aroma are acceptable.
\end{abstract}

Keywords: Anadara granosa, cireng snacks, protein, metals, sensorics quality

\section{INTRODUCTION}

Blood cockle (Anadara granosa) is one of the important cockle species used as a meal in Thailand, Malaysia (Watanabe 2009; Yurimoto et al. 2014) and Indonesia (Awang-Hazmi et al. 2007; Amriani et al. 2011; Taurusiana et al. 2014). Blood cockle is one of the food products that can be used as a source of protein in Sout East Asian region (Awang-Hazmi et al. 2017). This type of cockle is also a source of the mineral (Taniguchi et al. 2017). The blood cockle is a family of Arcidae from Anadara genus.

Blood cockle has various chemical composition depends on their species, sex, age, and habitat. The chemical composition for freshly cultivated cockles are protein $19.48 \%$, fat $2.0 \%$, moisture $74.37 \%$, ash $2.24 \%$, zinc $13.91 \mathrm{ppm}$, and $\mathrm{Ca} 698.49 \mathrm{ppm}$, whereas the boiled cockle has protein $23.23 \%$, fat $7.01 \%$, moisture $65.69 \%$, ash 2.57\%, Zn 12.99 ppm, and Ca 1320.76 ppm ( Nurjanah 2005). In addition, the zinc content in blood cockles cultivated from Malaysian water is $0.22 \mathrm{ppm}$ (Alkarkhi et al. 2008).

The blood cockles are often boiled, made into satay, and cooked with coconut milk. This indicates that the blood cockles still have many potentials to be processed into various highly nutritious and highly economic food products. One of this is through supplementation of flour made from blood cockles' meat in cireng snack production.
Cireng is traditional Indonesian snack made from friedtapioca flour dipped into sauces. Cireng is usually made from tapioca flour, some spices, and other ingredients. Hence, the highest nutrition element in this snack is carbohydrate. Conventional cireng made from tapioca flour has $50 \mathrm{~g}$ of carbohydrate; $0.5 \mathrm{~g}$ of protein; $0.3 \mathrm{~g}$ of fat in each $100 \mathrm{~g}$ of tapioca flour (Realita and Kristiatuti 2014). Cireng is people's favorite snack and often sold in places with high concentration of children, such as, schools.

As children's favorite snack, the level of nutrition in this snack needs to be increased to fulfill the children's nutrition. The supplementation of blood cockles in this snack could improve the nutrition content of the snack, especially its protein, zinc, and calcium, which are essential for the body. On the other hand, blood cockle is also prone to accumulate the metals from its surrounding area. Hence, it is possible for the blood cockle to accumulate the heavy metals as it is a ciliary feeder (as deposit feeder or filter feeder) (FAO 2012). These heavy metals can infiltrate the human body through consumption of this cockle. Among several heavy metals that are commonly found in blood cockle are $\mathrm{Pb}$ and $\mathrm{Hg}$. The maximum allowed limit of lead $(\mathrm{Pb})$ and Mercury $(\mathrm{Hg})$ is $0.1 \mathrm{mg} / \mathrm{kg}$ (SNI 2009). To support the safety of snack made from blood cockle and as safety measure toward its side effect, an analysis of heavy metals $(\mathrm{Hg}$ and $\mathrm{Pb})$ level on cireng snack made from blood cockle flour needs to be done. This study aims at evaluating the level of zinc, calcium, protein, $\mathrm{Pb}, \mathrm{Hg}$, and 
the sensorics quality of cireng snacks supplemented with blood cockle (Anadara granosa) flour.

\section{MATERIALS AND METHODS}

The ingredients in making cireng are blood cockle flour, tapioca flour, warm water, and spices (garlic, pepper, sugar, and salt). The blood cockles were taken from Pohuwato, Gorontalo Province, Indonesia. The flour was made at the Biology Laboratory of Gorontalo State University, Indonesia. The protein analysis was conducted at the Veterinary Faculty of Universitas Airlangga, Surabaya, Indonesia. Meanwhile, zinc, calcium, $\mathrm{Pb}$ and $\mathrm{Hg}$ analysis was carried out at Balai Besar Kesehatan Daerah Surabaya (Surabaya Health Institution), Indonesia. In addition, sensorics quality of cireng snack was conducted on elementary students in the District of Gorontalo Utara, Indonesia. The protein analysis used the analytical balance, burette, measuring glass, glass stirring, Kjeldahl tube, distillatory, distillation tube and pipet volume, ErleneMeyer tube, and tube and pipette. The calcium, zinc, $\mathrm{Pb}$ and $\mathrm{Hg}$ test used the furnace, and volumetric flask, Whatman paper, and Zeenit 700 of atomic absorption spectrophotometer. The calcium, zinc, $\mathrm{Pb}$, and $\mathrm{Hg}$ were measured in ppm, and the level of proximate (protein, fat, and carbohydrate) were measured in percent.

This study used complete randomised design. The treatments were the addition of blood cockle flour in the production of cireng snack with $0 \%, 5 \%, 10 \%, 15 \%$ and $20 \%$ concentrate. The additional of $0 \%-20 \%$ concentrate of blood cockle was based on the consideration of acceptable nutrition value. Protein level test used micro Kjeldahl method (AOAC 1995). Whereas, zinc, calcium, $\mathrm{Pb}$, and $\mathrm{Hg}$ level were tested using AAS method. Sensorics quality was determined organoleptically with the hedonic test.

The data were tested using Shapiro-Wilk, One Way ANOVA and Least Significance Difference tests on 95\% level of significance. The data were analyzed with SPSS program.

\section{RESULTS AND DISCUSSION}

\section{Cireng's protein level}

Protein is an important nutrition for the body due to its function as the workers within the cells; it develops and regulates the organs (Winarno 1997). The average protein level in $0 \%, 5 \%, 10 \%, 15 \%$, and $20 \%$ blood cockle supplemented cireng were $1.78 \%, 1.87 \%, 2.07 \%, 2.20 \%$, and $2.75 \%$. Blood cockle supplementation has increased the protein level by $5.05 \%, 12.36 \%, 23.59 \%, 54.49 \%$ compared to the treatment with no blood cockle supplementation. The ANOVA test revealed that blood cockle supplementation has significantly increased the protein level $(\mathrm{p}=0.006)$ (Table 1). The increase of protein in cireng is parallel with the increase of blood cockle concentrate supplemented into the cireng snack. Level of protein in cireng without blood cockle supplementation which was derived from tapioca flour was $2.01 \%$.

This research showed that the higher the blood cockle flour in cireng snack concentration. the higher the level of protein in it. The increase of protein level in cireng was due to the high level of total protein in blood cockle flour which was $27.26 \%$ (Solang 2014). The increase of protein level in cireng was parallel to the increase of blood cockle flour supplemented into the cireng ingredients. This study showed that the supplementation of blood cockle in this snack insignificantly increased the level of protein unlike the level of protein in blood cockle flour. This was suspected due to the denaturation during the cooking process of cireng snack (fried or boiled). Protein denaturation could happen due to heat, $\mathrm{pH}$, a chemical substance, mechanic, etc. (Winarno 1997). The level of protein in blood cockle supplemented cireng was equal to the level of protein on cireng filled with chicken floss $(2.8 \%)$ or on cheese filled cireng $(2.3 \%)$. However, the protein level was lower than that of meat floss filled cireng (3.5\%) (Realita and Kristiastuti 2014).Therefore, blood cockle supplemented cireng can become an alternative to add the protein level in cireng product. A hundred gram of blood cockle supplemented cireng with the concentrate of $5 \%$. $10 \% .15 \%$. and $20 \%$ can supply the daily protein need of $7-10$ years old children by $6.67 \% .7 .39 \% .7 .85 \%$. and $9.82 \%$. based on the level of daily protein intake $28 \mathrm{~g} /$ day (Gebhardt and Thomas 2002).

\section{Level of zinc in cireng}

Zinc can stimulate activities of 100 enzymes in the human body and is involved as a cofactor in 200 others. Lack of zinc intake could cause lack of immunity (Overbec et al. 2008; Prasad 2009). Zinc is primarily obtained from food. The major sources of zinc are (red) meat, poultry, fish and seafood, whole cereals and dairy products (Das and Das 2012). Zinc needs by the body can be fulfilled by various types of products.

The average level of zinc in $0 \%, 5 \%, 10 \%, 15 \%$, and $20 \%$ blood cockle supplemented cireng were $2.708 \mathrm{ppm}$, $2.958 \mathrm{ppm}, 3.057 \mathrm{ppm}, 3.068 \mathrm{ppm}, 3.307 \mathrm{ppm}$. Supplementation of $5 \%, 10 \%, 15 \%$, and $20 \%$ blood cockle into cireng's snack increased the level of zinc by $9.2 \%$, $12.9 \%, 13.3 \%$, and $22.1 \%$, compared to the control group. The ANOVA test showed that supplementation of blood cockle significantly increased the level of zinc in cireng snack $(p=0.031)$ and supplementation of $10 \%$ blood cockle into cireng snack showed significant differences compared to other treatments (Table 2).

Level of zinc in cireng snack supplemented with blood cockle was between $2.958 \mathrm{ppm}$ to $3.307 \mathrm{ppm}$; this was the average level of zinc in milk (3-5 ppm) (Ensminger 1995). A hundred gram of cireng supplemented with $5 \%, 10 \%$, $15 \%$, and $20 \%$ of blood cockle had $0.296 \mathrm{mg}, 0.306 \mathrm{mg}$, $0.307 \mathrm{mg}$, and $0.331 \mathrm{mg}$ of zinc. Badan Standardisasi Nasional (National Standardization Agency, henceforth called as BSN) had not set the maximum standard of zinc in snacks. Hence. cireng made with the supplementation of blood cockle is safe to be consumed. 
Table 1. Protein level (\%) of cireng with blood cockle flour supplemented

\begin{tabular}{|c|c|c|c|}
\hline Treatment & Average \pm SD protein level & Increase of protein level (\%) & $P$ value \\
\hline Control & $1.78 \pm 0.025^{\mathrm{a}}$ & - & 0.006 \\
\hline $5 \%$ supplementation of blood cockle flour & $1.87 \pm 0.037^{\mathrm{a}}$ & 5.05 & \\
\hline $10 \%$ supplementation of blood cockle flour & $2.07 \pm 0.068^{\mathrm{a}}$ & 12.36 & \\
\hline $15 \%$ supplementation of blood cockle flour & $2.20 \pm 0.100^{\mathrm{a}}$ & 23.59 & \\
\hline $20 \%$ supplementation of blood cockle flour & $2.75 \pm 0.534^{b}$ & 54.49 & \\
\hline
\end{tabular}

Note: $\mathrm{p}<0.005=$ significant. Different letter means significant difference based on LSD (0.05)

Table 2. The level of zinc (ppm) on cireng supplemented with blood cockle

\begin{tabular}{|c|c|c|c|}
\hline Treatment & Average \pm SD level of zinc & Increase of zinc level (\%) & $P$ value \\
\hline Control & $2.708 \pm 0.055^{\mathrm{a}}$ & - & 0.031 \\
\hline $5 \%$ supplementation of blood cockle flour & $2.958 \pm 0.201^{\mathrm{a}}$ & 9.2 & \\
\hline $10 \%$ supplementation of blood cockle flour & $3.057 \pm 0.137^{\mathrm{ab}}$ & 12.9 & \\
\hline $15 \%$ supplementation of blood cockle flour & $3.068 \pm 0.216^{\mathrm{ab}}$ & 13.3 & \\
\hline $20 \%$ supplementation of blood cockle flour & $3.307 \pm 0.239^{\mathrm{bc}}$ & 22.1 & \\
\hline
\end{tabular}

Note: $p<0.005=$ significant, different letter means significant difference based on LSD (0.05)

Table 3. Level of calcium (ppm) in cireng which supplemented with blood cockle

\begin{tabular}{|c|c|c|c|}
\hline Treatment & Average \pm SD level of calcium & Increase of calcium level (\%) & $P$ value \\
\hline Control & $6.805 \pm 0.048^{\mathrm{a}}$ & - & 0.016 \\
\hline $5 \%$ supplementation of blood cockle flour & $6.887 \pm 0.113^{\mathrm{a}}$ & 1.2 & \\
\hline $10 \%$ supplementation of blood cockle flour & $6.961 \pm 0.173^{\mathrm{a}}$ & 2.3 & \\
\hline $15 \%$ supplementation of blood cockle flour & $7.105 \pm 0.123^{\mathrm{ab}}$ & 4.4 & \\
\hline $20 \%$ supplementation of blood cockle flour & $7.193 \pm 0.110^{\mathrm{b}}$ & 5.7 & \\
\hline
\end{tabular}

Note: $p<0.005=$ significant. different letters means significant difference based on LSD (0.05)

Supplementation of blood cockle in cireng product can provide better zinc values compared to the conventional cireng made from tapioca. In addition, blood cockle also has complex amino acid. Hence, zinc in cireng can be easily absorbed by the body. Meanwhile, cireng made tapioca flour is suspected to have phytate which can inhibit zinc absorption in the body. In addition to the spices used in cireng production is suspected to have polyphenol that can also inhibit zinc absorption in the body (Damastuti et al. 2008). This has proved that combination of blood cockle flour in cireng is a better option to improve the nutrition content in cireng. especially zinc. Average daily need for zinc is 5-19 mg (Mulyaningsih 2009; Anon 2013). Hence, consumption of $100 \mathrm{mg}$ cireng made from $5 \%, 10 \%, 15 \%$, $20 \%$ supplementation of blood cockle can fulfill the minimum daily need of zinc by $5.92 \%, 6.12 \%, 6.14 \%$, and $6.2 \%$.

\section{Level of calcium (Ca) in cireng}

Calcium is a mineral that helps build and maintain strong bones and teeth. Getting enough calcium as a child is important for reaching his/her potential adult height; a lack of it can cause a stunting of growth (Stuijvenberg et al. 2014; Sari et al. 2016). Food sources of calcium are milk, Yogurt, Cheese, Spinach, Broccoli, Oranges, Salmon, and calciumfortified foods.
Average calcium level of $0 \%, 5 \%, 10 \%, 15 \%$, and $20 \%$ blood cockle supplemented cireng was $6.805 \mathrm{ppm}, 6.887$ ppm, 6.961 ppm, $7.105 \mathrm{ppm}$, and $7.193 \mathrm{ppm}$. Supplementation of blood cockle has increased the level of calcium by $1.2 \%, 2.3 \%, 4.4 \%$, and $5.7 \%$ compared to the control group. The ANOVA test showed that supplementation of blood cockle flour has significantly increased the level of calcium in cireng $(p=0.016)$, and the LSD test showed that $15 \%$ and $20 \%$ supplementation of blood cockle had a higher significance level of $\mathrm{Ca}$ compared to the control group. In addition, $15 \%$ and $20 \%$ supplementation of blood cockle flour had no significant difference (Table 3).

Level of calcium in cireng supplemented with blood cockle was between $6.887 \mathrm{ppm}$ to $7.193 \mathrm{ppm}$. The increase of calcium level in cireng was suspected from the blood cockle flour which contained $8.012 \mathrm{ppm}$ of calcium, compared to the tapioca flour which contained only 7.984 $\mathrm{ppm}$. The SNI had not set the standard of calcium level on cireng snacks. The daily requirement of calcium for children aged 7-9 years is $1000 \mathrm{mg}$ (Anon 2013). Hence, consumption of $100 \mathrm{mg}$ cireng made from $5 \%, 10 \%, 15 \%$, $20 \%$ supplementation of blood cockle can fulfil the minimum daily need of calcium by $0.69 \%, 0.69 \%, 0.71 \%$, dan $0.72 \%$ 


\section{Level of lead $(\mathbf{P b})$ in cireng}

Supplementation of tapioca flour with blood cockle flour in cireng snack production increased the level of $\mathrm{Pb}$ in this snack. The average level of $\mathrm{Pb}$ in cireng supplemented with $0 \%, 5 \%, 10 \%, 15 \%$, and $20 \%$ blood cockle flour increased by $0.128 \mathrm{ppm}, 0.146 \mathrm{ppm}, 0.150 \mathrm{ppm}, 0.155$ $\mathrm{ppm}$, and $0.160 \mathrm{ppm}$. The ANOVA test showed that supplementation of blood cockle in cireng snack increased the level of $\mathrm{Pb}(\mathrm{p}=0.000)$ by $14.06 \%, 19.19 \%, 21.09 \%$, and $25.00 \%$ compared to the control group. LSD test showed that all treatments were different from the control (no treatment); this showed that small portion's supplementation of blood cockle flour in this snack increased the level of $\mathrm{Pb}$ (Table 4).

This study also showed that the $\mathrm{Pb}$ level in control group was $0.128 \mathrm{ppm}$. This indicates that cireng, either made from pure tapioca flour or tapioca flour supplemented with blood cockle, contained $\mathrm{Pb}$. The laboratory test revealed that the level of $\mathrm{Pb}$ in cireng made from tapioca flour was $0.169 \mathrm{ppm}$ and from tapioca added with blood cockle flour was $0.173 \mathrm{ppm}$. The level of $\mathrm{Pb}$ in cireng was still below the safety level of $\mathrm{Pb}$, which was $0.25 \mathrm{mg} / \mathrm{kg}$ (ppm) (SNI 2009), i.e. $6 \mathrm{ppm}$ for all food in solid form (Choi 2011). Therefore, cireng supplemented with blood cockle flour is safe to be consumed.

\section{Mercury (Hg) level in cireng}

Mercury compound could be found anywhere, near polluted and dangerous places. The greater the seafood consumed, the higher the mercury intake (Burger 2000). Fish was the major source of total mercury intake for Taiwan population (74-83\%). The marine fish contributed the most, followed by shellfish and freshwater fish. The highest mercury level was found in tuna (Chen and Chen 2006).

The average level of $\mathrm{Hg}$ in control group product was $0.0013 \mathrm{ppm}$. Meanwhile, 5\%, 10\%, 15\%, 20\% blood cockle supplemented cireng contained $0.0023 \mathrm{ppm}, 0.0023$ ppm, $0.0027 \mathrm{ppm}$, and $0.0033 \mathrm{ppm}$. Supplementation of blood cockle has not significantly increased the level of $\mathrm{Hg}$ in cireng $(\mathrm{p}=0.022)$ (Table5).

This study shows in average the level of $\mathrm{Hg}$ in cireng product which supplemented with blood cockle has increased. Mercury in cireng was suspected to come from the blood cockle flour. The level of $\mathrm{Hg}$ in blood cockle was $0.0040 \mathrm{ppm}$. and the level of $\mathrm{Hg}$ from tapioca flour was $0.0020 \mathrm{ppm}$. Thus. cireng. both made from supplemented blood cockle or tapioca flour. contained Hg. The limit of $\mathrm{Hg}$ contamination in processed food is $0.03 \mathrm{mg} / \mathrm{kg}$ (ppm) (SNI 2009), and $0.5 \mathrm{ppm}$ (Choi 2011). Based on this study. the level of $\mathrm{Hg}$ in cireng supplemented with blood cockle was below the standard. Hence the cireng made with blood cockle flour from Gorontalo is safe to be consumed.

\section{Sensorics quality of cireng supplemented with flour made from blood cockle Taste}

The hedonic test showed that average panelists likeness toward the taste of this cireng were between 3.4-4.7 (somewhat disliked to liked).The highest average likeness of the panelists toward the taste of cireng supplemented with $10 \%$ of blood cockle flours. The ANOVA for the organoleptic test without control group showed that supplementation of blood cockle flour did not increase the level of panelists' likeness toward the taste of cireng significantly $(p=0.405)($ Table 6$)$. This study showed that panelists tend to like the supplementation of cireng by $0 \%$ and $10 \%$ and that panelists somewhat like the $5 \%, 15 \%$, and $20 \%$ supplementation of blood cockle flour in cireng product. The appropriate composition of cireng supplemented with the blood cockle flour is $10 \%$; panelists tend to consider that this blood cockle and tapioca flour's composition was appropriate.

The increase of blood cockle flour tends to lower the level of panelists likeness toward the taste; this is because the blood cockle flour has a unique taste that tends to increase the proportion of blood cockle flour's concentration. This is supported by Kumalaningsih (1986) who states that the taste of the food comes from the food itself and if there are additional ingredients added to the mixture, the taste will be influenced by those ingredients and the processing. In addition. panelists who are elementary students, were not used to consume blood cockles regardless that they live near the coastal area or not. The taste of food that is consumed daily actually consisted of a mixture of taste respond, aroma, and trigeminal response that were combined with other impressions such as sigh, touching, and hearing. Each ingredient in cireng product supplemented with blood cockle flour consists of three basic tastes, and the combination of those tastes composed the taste of the cireng product.

\section{Aroma}

People's acceptance toward the cireng aroma is the result of a physio-psychological reaction or personal impression of the panelists. The sensitivity of the panelists' smelling sense plays a major role in aroma test (Soekarto 1990). The average likeness of the cireng aroma was 2.84.6 (somewhat not like to like). ANOVA test (without control treatment) showed that supplementation of blood cockle flour is insignificant to the panelists' likeness toward the cireng's aroma ( $p=0.262)$ (Table 6).

The Aroma cireng in control treatment had the likeness score of 4.6 (like), whereas the aroma of cireng product with blood cockle supplementation earned the highest likeness score of 4.1 in the concentration of $10 \%$. Whereas. the $5 \%, 15 \%$, and $20 \%$ supplementation of blood cockle flour had the likeness score of the aroma which ranged between 2.8-3.7 (somewhat disliked to somewhat liked). The highest average likeness of the cireng's aroma was on $10 \%$ treatment. Whereas the least liked cireng was the product supplemented with $20 \%$ of blood cockle flour, this is because this product has the strongest blood cockle aroma compared to other treatments. The higher the blood cockle percentage supplemented into the cireng, the fishier the aroma. 
Table 4. Level of $\mathrm{Pb}(\mathrm{ppm})$ in cireng supplemented with blood cockle flour

\begin{tabular}{|c|c|c|c|c|}
\hline Treatment & $\begin{array}{c}\text { Average level } \pm \text { SD of } \mathrm{Pb} \\
(\mathrm{ppm})\end{array}$ & $\begin{array}{c}\text { Increase of } \\
\text { Pb level (\%) }\end{array}$ & $\begin{array}{c}P \\
\text { value }\end{array}$ & $\begin{array}{c}\text { Average safety standard } \\
\text { (SNI 2009) }\end{array}$ \\
\hline Control & $0.128 \pm 0.003^{\mathrm{a}}$ & & 0.000 & $0.25 \mathrm{mg} / \mathrm{kg}$ \\
\hline $5 \%$ supplementation of blood cockle flour & $0.146 \pm 0.003^{\mathrm{b}}$ & 14.06 & & \\
\hline $10 \%$ supplementation of blood cockle flour & $0.150 \pm 0.004^{b}$ & 17.19 & & \\
\hline $15 \%$ supplementation of blood cockle flour & $0.155 \pm 0.002^{\mathrm{bc}}$ & 21.09 & & \\
\hline $20 \%$ supplementation of blood cockle flour & $0.160 \pm 0.003^{\mathrm{c}}$ & 25.00 & & \\
\hline
\end{tabular}

Note: $p<0.005=$ significant, different letters means significant difference based on LSD (0.05).

Table 5. Level of $\mathrm{Hg}(\mathrm{ppm})$ in cireng supplemented with blood cockle flour

\begin{tabular}{|c|c|c|c|c|}
\hline Treatment & $\begin{array}{c}\text { Average } \pm \text { SD level of } \mathrm{Hg} \\
(\mathrm{ppm})\end{array}$ & $\begin{array}{c}\text { Increase of } \mathrm{Hg} \\
\text { level }(\%)\end{array}$ & $\begin{array}{c}P \\
\text { value }\end{array}$ & $\begin{array}{l}\text { Safety level } \\
\text { (SNI 2009) }\end{array}$ \\
\hline Control & $0.0013 \pm 0.0005^{\mathrm{a}}$ & - & 0.022 & $0.03 \mathrm{mg} / \mathrm{kg}$ \\
\hline $5 \%$ supplementation blood cockle flour & $0.0023 \pm 0.0005^{\mathrm{b}}$ & 76.92 & & \\
\hline $10 \%$ supplementation blood cockle flour & $0.0023 \pm 0.0005^{\mathrm{b}}$ & 76.92 & & \\
\hline $15 \%$ supplementation blood cockle flour & $0.0027 \pm 0.0005^{\mathrm{b}}$ & 107 & & \\
\hline $20 \%$ supplementation Blood cockle flour & $0.0033 \pm 0.0005^{\mathrm{b}}$ & 153 & & \\
\hline
\end{tabular}

Note: $\mathrm{p}<0.005=$ significant, different letters means significant difference based on LSD (0.05)

Table 6. Sensorics quality of cireng supplemented with blood cockle flour

\begin{tabular}{|c|c|c|c|c|c|c|}
\hline $\begin{array}{c}\text { Parameter of } \\
\text { organoleptic } \\
\text { test }\end{array}$ & Control & $\begin{array}{c}5 \% \\
\text { supplementation of } \\
\text { blood cockle flour }\end{array}$ & $\begin{array}{c}\text { Treatment } \\
10 \% \\
\text { supplementation of } \\
\text { blood cockle flour }\end{array}$ & $\begin{array}{c}15 \% \\
\text { supplementation of } \\
\text { blood cockle flour }\end{array}$ & $\begin{array}{c}20 \% \\
\text { supplementation of } \\
\text { blood cockle flour }\end{array}$ & $\begin{array}{c}P \\
\text { value }\end{array}$ \\
\hline Taste & $4.6 \pm 1.3$ & $3.8 \pm 1.6$ & $4.7 \pm 1.4$ & $3.9 \pm 1.5$ & $3.4 \pm 2.2$ & 0.405 \\
\hline Aroma & $4.6 \pm 1.5$ & $3.7 \pm 1.4$ & $4.1 \pm 1.4$ & $3.6 \pm 1.4$ & $2.8 \pm 1.5$ & 0.262 \\
\hline Colour & $4.9 \pm 1.7$ & $4.5 \pm 0.9^{\mathrm{a}}$ & $4.7 \pm 1 .^{2 \mathrm{ab}}$ & $3.5 \pm 0.9^{\mathrm{bc}}$ & $2.7 \pm 1.3^{\mathrm{c}}$ & 0.001 \\
\hline Texture & $3.7 \pm 1.3$ & $3.0 \pm 1.4^{\mathrm{a}}$ & $3.5 \pm 1.4^{\mathrm{a}}$ & $3.3 \pm 1.8^{\mathrm{a}}$ & $4.1 \pm 1.9^{\mathrm{a}}$ & 0.512 \\
\hline
\end{tabular}

Note: $\mathrm{p}<0.005=$ significant, different letters means significant difference based on LSD (0.05).

\section{Color}

The cireng supplemented with blood cockle flour has levels of likeness toward the color with the score between 2.7-4.9 (somewhat liked to liked).The highest likeness toward the color of cireng was on the cireng without blood cockle flour supplementation. Meanwhile, for the cireng product supplemented with blood cockle, the highest score for the color was on the $10 \%$ concentrate, 4.7 (liked) compared to another percentage of supplementation. The $15 \%$ and $20 \%$ concentrate of the supplementation earned the somewhat disliked score. The ANOVA test showed that supplementation of blood cockle decreased the likeness toward the color. The LSD test revealed that 5\% supplementation had significant difference compared to the $10 \%, 15 \%$, and $20 \%$ supplementation (Table 6).

This study showed that supplementation of blood cockle produced a brownish-yellow color and the highest the percentage of blood cockle supplementation made the darker color. It was suspected due to the natural color of the blood cockle flour which was brown. The brown color was produced during the drying process (Brennan 2006) and due to the reaction of sucrose sugar (glucose and fructose) with protein in blood cockle flour (Maillard reaction).

\section{Texture}

The texture of a food product was influenced by the main ingredient and the treatment during the processing, where the texture influenced the taste of the product. Acceptance of the texture was a physio-psychological respond or panelist personal impression on the quality of a tested food product (Soekarto 1990). Average panelists preference toward the texture of cireng made from supplemented blood cockle was between 3.0-4.1 (somewhat liked to liked). Panellists tend to like the texture of cireng supplemented with $20 \%$ of blood cockle flour. The ANOVA test (without control treatment) showed that supplementation of blood cockle flour did not significantly influence the preference level toward the texture of cireng $(\mathrm{p}=0.512)$ (Table 6).

Based on the average likeness score toward the texture, cireng with $20 \%$ supplementation blood cockle flour had the highest likeness compared to the other types of blood cockle flour concentration supplemented into the cireng 
product and the control group. This study showed that the supplementation of blood cockle flour into cireng product improved the texture of cireng. The control product which used only tapioca flour needs more water in its mixture.This was due to the high level of amylopectin concentration in tapioca flour, which hence, absorbed more water. Tapioca flour had oval shape granules with 5-35 micron in size, $17 \%$ of amylose, $83 \%$ of amylopectin and gelation temperature of $52-64^{\circ} \mathrm{C}$ (Ariani 2010). In this study, the number of water added to each treatment was equal. Hence, the cireng dough made only from tapioca flour became harder.

Meanwhile, cireng supplemented with blood cockle flour needed only a small amount of water. This was suspected due to the high level of fat within the blood cockle flour. Hence the dough supplemented with blood cockle flour was softer. The blood cockle flour contained a higher level of fat (6.61\%) compared to tapioca flour which was only $1.09 \%$. The higher the supplementation of blood cockle flour, the softer the cireng mixture. Thus, the panelists liked it more.

As conclusion. supplementation of blood cockle flour increased the level of protein, Zinc, Calcium, Lead, and mercury in cireng. However, the level of lead $(\mathrm{Pb})$ and mercury $(\mathrm{Hg})$ were still below the allowed standard set by the SNI (2009). Acceptance of the taste of cireng supplemented with blood cockle flour ranged from somewhat liked to liked. Panellists said that they preferred the taste of $10 \%$ supplemented blood cockle flour most. The acceptance of aroma of the cireng supplemented with blood cockle flour ranged from somewhat disliked to disliked. Panellists mentioned that they preferred the 5\% blood cockle flour supplementation. Acceptance toward the color of cireng snack ranged from somewhat liked to liked. Panellists said that they preferred the color of 5\% blood cockle flour supplementation. The acceptance of the texture of cireng ranged from somewhat liked to liked. Panellists preferred $20 \%$ blood cockle flour supplementation. Supplementation of blood cockles from Gorontalo Province, Indonesia in the flour used in making the cireng snacks produced snacks with a better nutrition value and safe to consume. Also, the flavor, color, texture, and aroma are acceptable.

\section{ACKNOWLEDGEMENTS}

We would like to thank the Institute for Research and Community Service, Gorontalo State University, Indonesia which has funded the implementation of this research activity.

\section{REFERENCES}

Alkarkhi A. F.M, Ismail N, Easa A M. 2008. Assessment of arsenic and heavy metal contents in cockles (Anadara granosa) using multivariate statistical techniques. Journal of Hazardous Materials 150: 783-789.

Amriani, Hendrarto B, Hadiyarto A. 2011. Bioaccumulation of heavy metals lead $(\mathrm{Pb})$ and zinc $(\mathrm{Zn})$ in blood cockles (Anadara granosa L.) and mangrove cockles (Polymesoda bengalensis L.) from Kendari Bay. Jurnal Ilmu Lingkungan 9 (2): 45-50. [Indonesian]
Anon. 2013. Indonesian recommended nutrition sufficiency. Health Ministerial Regulation of Republic of Indonesia Number 75 . [Indonesia]

AOAC [Association of Official Analytical Chemist]. 1995. Official methods of analysis of the association of official analytical chemist. 18th ed. AOAC International, Gaithersburg. USA,

Ariani M. 2010. Diversification of Indonesian food consumption. Analysis Centre of Bogor Social Economy and Agricultural Policy. [Indonesia]

Awang-Hazmi AJ, Zuki ABZ, Noordin MM, Jalila A, Norimah Y. 2007. Mineral composisi of the Cockle (Anadara granosa) Shells ofWest Coast of Peninsular Malaysia and Its potensial as biomaterial for use in bone repair. J Anim Vet Adv 6 (5): 591-594.

Burger. J. 2000. Gender differences in meal patterns: role of self-caught fish and wild game in meat and fish diets. Environ Res Sect A 83: 140-149.

Chen YC. Chen MH. 2006. Mercury levels of seafood commonly consumed in Taiwan. J Food Drug Anal 14 (4): 373-378.

Choi YY. 2011. International/National Standards for Heavy Metals in Food. Government Laboratory. Government of the Hong Kong SAR, Hong Kong.

Damastuti E, Muhayatun, Kurniawati S, Adventini N. 2008. Determination of $\mathrm{Zn}$ element in some foods by using neutron activation analysis. Proseding Seminar Nasional AAN. 127-34. SABUGA-Bandung, 22 Oktober 2008 [Indonesia]

Das M, Das R. 2012. Need of education and awareness towards zinc supplementation: A review. International Journal of Nutrition and Metabolism. 4 (3): 45-50.

Ensminger AH, Konlande SE, Robson JRK. 1995. The Concise Encyclopedia of Food \& Nutrition. CRC Press, Boca Roton, USA.

FAO. 2012. Species fact sheets Anadara granosa (Linnaeus. 1758). Fisheries and Aquaculture Department. FAO, Rome.

Gebhardt SE, Thomas. RG. 2002. Nutritive value of foods. U.S. Department of Agriculture. Agricultural Research Service. Nutrient Data Laboratory. Beltsville, Maryland.

Kumalaningsih S. 1986. Food and nutrition science. Faperta.Universitas Brawijaya, Malang. [Indonesia]

Mulyaningsih TR. 2009. The content of $\mathrm{Fe}$ and $\mathrm{Zn}$ elements in Agriculture. Live Stock and Fishery Foodstuff Products by Using k0AANI Method. Jurnal Sains dan Teknologi Nuklir Indonesia. X (2): 71-80. [Indonesia]

Nurjanah, Zulhamsyah, Kustiyariyah. 2005. The mineral content and proximate of blood cockle (Anadara granosa) from Boalemo District. Gorontalo. Buletin Teknologi Hasil Perikanan 8 (2): 15-24. [Indonesian]

Overbec S, Rink L, Haase H. 2008. Modulating the immune response by oral zinc supplementation: a single approach for multiple diseases. Arch Immunol Ther 56: 15-30.

Prasad AS. 2009. Zinc: role in immunity, oxidative stress and chronic inflammation. Curr Opin Clin Nutr Metab Care 12:646-652.

Realita RD, Kristiastuti SD. 2014. The diversity of cireng snacks. eJournal Boga 3 (3): 68-75. [Indonesian]

Sari EM, Juffrie M, Nurani N, Sitaresmi MN. 2016. Protein. calcium and phosphorus intake in stunting and not stunting child. Jurnal Gizi Klinik Indonesia 12 (4): 152-159. [Indonesian]

SNI [Indonesian National Standard]. 2009. Maximum limit of food heavy metal contamination. Badan Standardisasi Indonesia. SNI 7387. [Indonesian]

Soekarto, Soewarno T. 1985. Organoleptic Assessment for the Food Industry and Agricultural Products. Bhratara Karya Aksara, Jakarta. [Indonesian]

Solang M. 2014. Analysis of Blood Cockle (Anadara granosa) Flour Provision on Levels of Albumin. Zinc. IGF-I. Length and Weight of Bone Femur. and Body Weight (Experimental Research Laboratory in Malnourished Male Rats (Rattus norvegicus). [Dissertation]. Universitas Airlangga. Surabaya. [Indonesian]

Stuijvenberg ME van, Nel J, Schoeman SE, Plessis LM du, Dhansay MA. 2014. Low intake of calcium and vitamin D is associated with stunting in 2-5-year-old children from an impoverished South African community. Poster presentation at Micronutrient Forum. Addis Ababa. Ethiopia. 2-6 June 2014.

Taniguchi CN, Dobbs J, Dunn MA. 2017. Heme iron, non-heme iron, and mineral content of blood clams (Anadara spp.) compared to Manila clams (V. philippinarum), Pacific oysters (C. gigas), and beef liver (B. taurus). Journal of Food Composition and Analysis 57: 49-55.

Taurusiana S, Afiati N, Widyorini N. 2014. Study of iron (Fe) and zinc $(\mathrm{Zn})$ content in soft tissues of blood cockles (Anadara granosa L.) 
from coastal areas of Tanjung Mas, Semarang and Wedung, Demak, Diponegoro. J Maquares Manag Aquat Res 3 (1): 143-150. [Indonesian].

Watanabe K. 2009. Coastal-zone use of Bandon bay: area study in Surat Thani province. South Thailand. Kyoto Working Papers on Area Studies: G-COE Series 68: 1-12.
Winarno FG. 1997. Food and Nutrition Chemical Process. PT. Gramedia, Jakarta. [Indonesian]

Yurimoto T, Mohd K F, Man A. 2014. Sexual maturation of the blood cockle. Anadara granosa. in Matang mangrove estuary. peninsular Malaysia. Intl J Aquat Biol 2 (3): 115-123. 